\title{
PARAMPHISTOMUM ICHIKAWAI IN CATTLE IN SOUTHERN MORAVIA
}

\author{
B. KOTRLÁ, K. CHROUST \\ Institute of Parasitology, Czechoslovak Academy of Sciences, 16632 Prague; State Veterinary \\ Institute for Game, Jihlava \\ Received fune 1, 1978
}

\begin{abstract}
Kotrlá B., K. Chroust: Paramphistomum ichikawai in Cattle in Southern Moravia. Acta vet. Brno, 47, 1978: 97-101.

The first case of paramphistomatosis in Central Europe was diagnosed in 1-1,5-year-old cattle in southern Moravia. Presented is also information on the newest concepts concerning the existence of the species $P$. scotiae.
\end{abstract}

Paramphistomatosis, P. scotiae, determination, morphology.

\section{Material and Methods}

The trematodes parasitized in the rumen of 8 young cows originating from a co-operative farm at Nejdek, district of Břeclav. The trematodes intended for morphological (anatomical) studies were fixed in $4 \%$ formol and fixation was completed in $10 \%$ formol. Further treatment was conducted by means of common histological techniques and staining in HE and trichrome. Serial histological sections were prepared from 10 trematode specimens obtained from four host animals. As the basis of our studies on evaluation of individual taxons was taken the monograph by Näsmark from 1937. However, we considered the newest criteria elaborated by Sey (1974) with regard to other works (Wilmott, 1950; Veličko 1967, 1969, 1971; Vujić et al. 1971 etc.).

\section{Results}

All trematodes treated belonged to the species Paramphistomum ichikawai. Since this species has not so far been described in our literature and new errors and mistakes appear while designating criteria for the differentiation of individual species, its detailed description is presented:

Description: the smallest mature specimens are $4 \mathrm{~mm}$, the longest ones $6.8 \mathrm{~mm}$ long, $1.5-2.0 \mathrm{~mm}$ wide. (Trematodes parasitizing game measured 4-6.5 $\times$ $\times 2.0-2.8 \mathrm{~mm}$ ). Body crescent-shaped on the ventral side. Pharynx, Calicophoron type, in terminal position, $0.481-0.535 \mathrm{~mm}$ long, in proportion to body length $1: 7.4-10.2$. Both circular internal and external muscle layer well-developed, conspicuous on the whole length of the pharynx, in contrast to middle muscles, conspicuous only in its base. Internal longitudinal muscle layer reach about $1 / 3$ of the width of the pharynx, external longitudinal muscles are extended in a narrow, though clearly conspicuous strip. Radial muscles formed by scarce fibres. The mid-part of the pharynx provided with numerous papillae. Oesophagus $0.428-0.502 \mathrm{~mm}$ long.

Acetabulum of Paramphistomum type in subterminal position, measuring 
$0.949 \times 1.4 \mathrm{~mm}$, in proportion to body length $1: 3-(3.3)$. Dorsal external muscle grouped in 2 separated parts: $d_{1}=16-22$ muscles, $d_{2}=8-16$. Internal muscles $-d i=40-51$. The number of units in the ventral external muscle layer $-v e=12-16$, in the internal one $-v i=45-53$.

Genital atrium is well-developed, without genital sphincter, though that on the papillae present. Radial muscles formed by scattered muscle bands. Testes are oval, tandem, lobated, located in the second third of the body and measure $0.642-0.782 \times 0.963-1.1 \mathrm{~mm}$. Both pars musculosa and pars prostatica of vas deferens are moderately developed. Mehlis' gland, oval and small, attached to oval ovary measuring $0.484 \times 0.286 \mathrm{~mm}$, situated between the 2 nd testis and the acetabulum. Excretory bladder terminates $1.7-2 \mathrm{~mm}$ far from body end. The vitellaria extend along the sides of the body. Eggs measure $0.114-0.123 \times$ $\times 0.061-0.066 \mathrm{~mm}$.

\section{Discussion}

Geographical distribution of this species is rather wide. It was described by Fukui 1922 from Japanese Bos taurus. While conducting the revision of the material from the Australian cattle in 1951, Durie found that the trematodes designated as Paramphistomum colicophorum were in fact the species $P$. ichikawai, though some measurements were different from those presented by Näsmark, 1937 in his monograph. In the USSR, where several workers (Velićko 1964, 1967, 1969, 1971; Nikitin 1967; Katkov 1971; Katkov et al. 1971 etc.) dealt with the problems of paramphistomatosis of domestic animals, it was found that $P$. ichikawai is abundant in sheep in the Amur region, in the sea-side in Buryatia and in Ukraina. It was also found in the sika. The species has not been reported from Cuba, America, Africa and India. In Europe, it occurs primarily in sheep and game in Yugoslavia (Vujić 1965) and in Hungary, principally in sheep, though it was found infecting also cattle (S ey 1974). In Czechoslovakia it was recovered by Erhardová (1964) from red deer and incorrectly designated as Ceylonocotyle scoliocelium, as proved by Velichkovova. The parasite has not yet been reported from other European countries, which may be caused by rather complicated preparations of the trematodes for determination. The future will show if the range of distribution is broader. In Poland, Anczykowski et al.(1955), Zadura et al. (1952), Patyk (1960), Romaniuk (1973), have reported the species $P$. cervi only, though the question of its existence is disputable. Therefore the problem of the specific representation of trematodes has not yet been solved.

Fig. 1.

Paramphistomum ichikawai. a - acetabulum, c - coecum, e - excretory vesicle, $\mathrm{g}$ - genital atrium, $\mathrm{m}-$ Mehlis gland, $\mathrm{o}$ - ovary, $\mathrm{p}-$ pharynx, $\mathrm{t}-$ testes, $\mathrm{u}-$ uterus, $\mathrm{v}-$ vitellaria

Fig 2.

Genital atrium Ichikawai - type

Fig. 3.

Pharynx Calicophoron - type

Fig. 4.

Acetabulum, Paramphistomum - type. $\mathrm{d} \mathrm{e}_{1}-\mathrm{de}_{2}$ dorsal exterior circular layer, $\mathrm{d} \mathrm{i}$ - dorsal enterior circular layer, $\mathrm{ve}-$ ventral exterior circular layer, $\mathrm{v} i$ - ventral interior circular laye $\mathrm{r}$ 

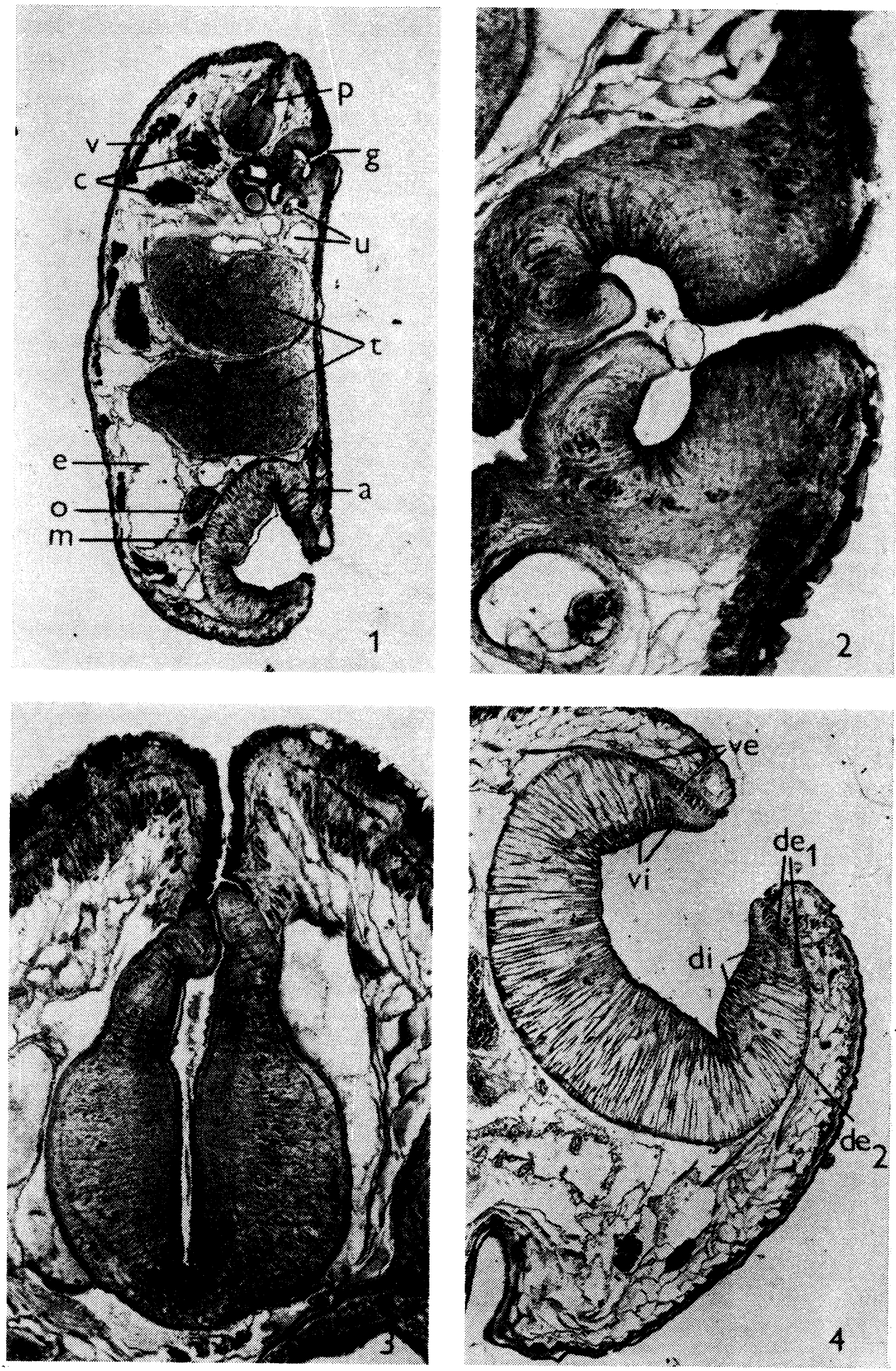
In other states of Central and Western Europe, too, the occurrence of trematodes belonging to the family Paramphistomatidae has not been studied in detail and only future investigations may show which species occur there. On the basis of the description by Wilmott the following species have been presented until now: $P$. hiberniae, $P$. scotiae and $P$. cervi. Nevertheless, their validity is questionable. It was indicated that $P$. hiberniae and $P$. scotiae are identical (oral notification byl Wilmott 1973; Veličko 1971). Of conspicuous similarity are also the species $P$. scotiae and $P$. leydeni. Of 9 differentiating features presented in the descriptions by Wilmott - body length, the shape of testes, location of excretory bladder in relation to the acetabulum, the opening of the excretory pore, development of the pharyngeal papillae, proportion of the acetabulum to body length, location of genital atrium in relation to the ending of oesophagus, the shape of genital atrium, length of excretory canal - the first five characters correspond to the individual variability, other four are subjected to the changes induced by fixation and staining during preparations of slides. This fact is also stressed by Sey (1974) who studied in detail morphological-anatomical characters of the genus Paramphistomum in Hungary. Comparative studies carried out by this author indicate that the species $P$. scotiae and $P$. leydeni are identical.

Consequently, further morphological studies of trematodes of the rumen are necessary to conduct in Slovakia, where, as stated by Pačen ovský, (1974) the species $P$. scotiae occurs (the genus Liorchis, established by Veličko on the basis of the musculature of pharynx and the acetabulum is invalid).

From the view of veterinary practice seriousness of invasions with the trematodes of the rumen should not be underestimated. Strong evidence for this provide literature data from neighbouring states, e. g. Poland, Hungary, Bulgaria and Yugoslavia, where the occurrence of paramphistomatosis is on the increase. Paramphistomatosis of cattle is distributed also in some regions of Czechoslovakia (the River Dyje basin, southern Moravia). Chroust (1964, 1973) detected clinical symptoms of acute and chronical paramphistomatosis in young grazing cattie dissection findings revealed $1500-30000$ trematode specimens in the rumen of a single beast. With regard to preventive and control measures it is necessary to know also the specific representation of the trematodes. Each of these species has its own life-cycle as well as different snail groups serve as intermediate hosts to them (Planorbidae to $P$. ichikawai, Lymnaeidae to $P$. daubney etc.).

\section{Paramphistomum ichikawai u skotu na jižní Moravě}

Na jižní Moravě bylo nalezeno u $1-1,5$ roku mladého skotu Paramphistomum ichikawai. Je to první nález tohoto druhu u skotu ve střední Evropě. V práci je také poukázáno na nejnovější názory, týkající se existence druhu $P$. scotiae.

\section{Paramphistomum ichikawai крупного рогатого скота южной Моравии}

В южной Моравии было обнаружено Paramphistomum ichikawai крупного рогатого скота в возрасте $1-1,5$ года. Речь идет о первой находке в своем роде в средней Европе. В работе отмечаются новейшие точки зрения, касающиеся существования вида P. scotiae. 


\section{References}

ANCZYKOWSKI, F. - CHOWANIEC, W.: W sprawie pojawienia sie masowej inwazji Paramphistomum cervi u bydla w gromadzie. Med. wet., 11, 1955: 531.

DAVIDOVA-VELICKKO, I. V.: Occurrence of Paramphistomum ichikawai Fukui, 1922 in cattle in the USSR. Trudy vses. inst. Gel'mint., 11, 1951: 207-209.

DURIE, P. H.: The Paramphistomes (Trematoda) of Australian ruminants. Proc. Linnean Soc. New South Wales, 76, 1951: 41-48.

DURIE, P. H.: The paramphistomes (Trematoda) of Australian ruminants. II. The life history of Ceylonocotyle streptocoelium (Fischoeder) Näsmark and of Paraphistomum ichikawai Fukui. Australian J. Zool., 1, 1953: 193-222.

ERHARDOVÁ, B.: K systematickému postavení motolic z podčeledi Paramphistomatidae ve střední a jihovýchodní Evropě na základě morfologických znaků. Čs. Parasitol., 11, 1964: 145 to 150 .

CHROUST, K.: Paramphistomatóza mladého skotu. Veterinářství, 14, 1964: 104-107.

CHROUST, K.: Efficiency of the Anthelmintic Terenol (Resorantel) against the Fluke Paramphistomum (Liorchis) scotiae in Cattle and against the Tapeworms Moniezia sp. in Lambs. Acta vet. Brno, 42, 1973: 281-286.

KATKOV, M. V.: Morfologija miracidija Paramphistomum ichikawai Fukui, 1922 (Trematoda: Paramphistomidae). Tr. vsesv. inst. gelm. K. J. Skrjabina, 18, 1971: 11-114.

NÄSMARK, K. E.: A revision of the Trematode Family Paramphistomidae. Zool. Bidrag, Uppsala, 16, 1937: 301-565.

NIKITIN, V. F.: Izučenije biologii Liorchis scotiae (Willmott, 1950) Velichko, 1966 (Paramphistomata). Trudy vses. inst. gelmint., 14, 1967: 251-262.

PACENOVSKÝ, J. - KRUPICER, I. - MURÁR, B.: Paramfistomatóza prežúvavcov na Slovensku. Veterinářství, 3, 1974: 110-112.

PATYK, S.: Helminths in the alimentary tract of cattle in West Poland. Acta Paras. Polonica, 8, 1960: $231-253$.

ROMANIUK, K.: Parazytozy bydla na Zulawach. II. Paramfistomatoza i warunki jej szerzenia sie. Zeszyty naukowe. Akad. Roln.-techn. w Olsztynie, 1973: 97-103.

SEY, O.: On the species of Paramphistomum of cattle and sheep in Hungary. Acta Vet. Acad. Sci. Hungaricae, 24, 1974: 19-37.

SEY, O.: On the validity of Paramphistomum microbothrioides Price et McIntosh, 1944 (Trematodes). Acta Zool. Acad. Sci. Hungaricae, 20, 1974: 183-186.

VELIČKO, I. V.: Liorchis n. g. (Trematoda: Paramphistomidae). Mater. nauch. Konf. vses. Obshch. Gel'mint., 5, 1966: 70-80.

VELICKK, I. V.: Metodika izučenija morfologii paramfistomatid žvačnych (Trematoda: Paramphistomatidae). Trudy VIGIS, 15, 1969: 53-60.

VELIČKO, I. V.: O paramfistomatidach žvačnych v SSSR. Sb. rab. po gel. $M$ „Kolos“, 1971: $61-74$.

VUJIĆ, B.: Paramfistomoza preživara i principi odredivanja pripadnosti ovih parazita. Veterinaria, Saraj., 14, 1965: 471-478.

VUJIĆ, B. - PETROVIĆ, Z.: A contribution to the knowledge of Paramphistomides in Yugoslavia and their determination. I. multicolloque européen de parasitologie, Rennes, Frances, 1971: 388-390.

WILLMOTT, S.: On the species of Paramphistomum Fischoeder, 1901 occurring in Britain and Ireland with notes on some material from the Netherlands and France. J. Helminth., 24, 1950: $155-170$.

WILLMOTT, S. - PESTER, F. R. N.: The Discovery of Paramphistomum hiberniae Willmott, 1950 and its Intermediate Host in the Channel Islands. J. Helminth., 29, 1955: 1-2.

YAMAGUTI, S.: Synopsis of Digenetic Trematodes of Vertebrates. Tokio, 1971: 1-1074.

ZADURA, J. - NIEĆ, L.: Robaczyca zoladka u krowy wywolana przez przywzy Paramphistomum cervi. Med. vet., 8, 1952: 370. 